\title{
THE LITTLE NETWORK THAT COULD: \\ FCC RESTRICTIONS ON FOREIGN OWNERSHIP
}

I. INTRODUCTION

II. THE BIRTH OF A NETWORK

A. Foreign Beginnings

B. The Network Grows Up: The Troubled Teenager

C. The Champion, NBC, Enters the Ring

D. The Book Deal Gone Bad

III. FCC RESTRICTIONS ON FOREIGN ONWERSHIP

A. German Invaders and Section 310(b)

B. Section 310(b) Today

C. Case Law Interpreting Section 310(b)

IV. NAFTA, GatT, Cultural Protectionism, and How Section 310(B) IS HURTING THE AMERICAN BROADCASTING INDUSTRY

A. Canada's Cultural Industry Exclusion Clause

B. The EC's Green Paper

C. GATT

D. The Prisoner's Dilemma

V. POSSIBLE SOLUTIONS TO FOREIGN OWNERSHIP RESTRICTIONS

A. The "Do Nothing" and "Let the Courts Handle It" Solution.

B. Inclusion in Section $\mathbf{3 1 0}$ of a New Subsection (f).

C. Deregulation -- Back to the NBC-Fox Battle

VI. CONCLUSION

\section{INTRODUCTION}

When it was announced in 1994 that the United States would be deciding on the North American Free Trade Agreements, there was reaction. Likewise, when it was announced that the United States would join other nations in adopting the latest Uruguay Rounds of the General Agreement on Tariffs and Trade, the American public engaged in debate. But when it appeared as though their Thursday evening Simpsons viewing schedule might be internupted due to an obscure FCC regulation, the American public went into uproar.

Of course, this is an exaggerated viewpoint of the recent battle between General Electric Company's National Broadcasting Corporation ("NBC") and Rupert Murdoch's Fox Television Stations, Inc. However, it may be the best way to begin a discussion of a relatively forgotten area of administrative law that stood to cripple an up-and-coming network and significantly impacts one of the 
largest industries in our country: the entertainment broadcast industry. ${ }^{1}$ This article represents a light-hearted chronicling of the events leading up to NBC's filing with the FCC which compelled the FCC to take action against NBC's newest competitor, Fox. Section Three will look at the underlying regulations of the FCC that led to this controversy. Section Four will examine the rationale behind these regulations. Finally, Section Five will discuss the FCC's reaction and congressional steps taken in response. Specifically, Section Five will discuss the future role of the FCC and its ability to impose limitations on foreign ownership.

\section{THE BIRTH OF A NETWORK}

\section{A. Foreign Beginnings}

Since its invention some 50 years ago, millions of Americans have grown up watching the television. ${ }^{2}$ The majority of this time was spent watching one of the "Big Three," NBC, American Broadcasting Company ("ABC"), or Columbia Broadcasting System ("CBS"). In the 1970's cable television made its way into American homes, but only made a dent in the viewing market share of the "Big Three."

In 1985, an Australian publisher, Rupert Murdoch, made his way into the broadcasting arena. ${ }^{3}$ At the time, Murdoch owned Fox Films with Marvin Davis, an oil man from Denver. ${ }^{4}$ In May of that year, Metromedia, Inc., based in Secaucus, New Jersey, agreed to sell seven television stations to Twentieth Holdings, a company formed by Murdoch and Davis to buy broadcast stations. ${ }^{5}$ Subject to FCC approval and to Murdoch becoming a United States citizen, Twentieth Holdings was to buy the seven stations from Metromedia for more

1. All together, the entertainment industry is the second largest exporting industry behind aircraft. Lowell Forte, Film Industry Left Out of Landmark Trade Pact, CORP. LEGAL TIMEs, June 1994, at 14. This industry accounted for nearly $\$ 8$ billion in exports last year alone. John Follain, Hollywood Warns Europe in Movie Row, Reuter Newswire, September 5, 1994.

2. A determination of whether this is a positive or negative is far beyond the scope of this paper. I merely state fact.

3. Mr. Murdoch, though a newcomer to American broadcasting, had previous dealings with the entertainment (or information) industry through his ownership of several newspapers and publications around the country. For example, at the time, Murdoch owned various newspapers including the New York Post, the Chicago Sun-Times, and the Boston Herald. Stuart Taylor, Jr., Witch-hunt or Whitewash? AM. LAW., Apr. 1995 at 60. Ownership of these newspapers would come to present trouble for Murdoch.

4. Initially, it appeared as though the company owned by Murdoch and another businessman, Marvin Davis, would merge with New Jersey-based Metromedia. See Michael Cieply and Bill Abrams, Fox Film, Metromedia Are Discussing Some Sort of Combination, Sources Say, WAI.L. ST. J., May 1, 1985, at B7.

5. Metromedia Reaches Definitive Pact on Sale of Seven TV Stations, WALL. ST. J., May 21, 1985, at A47. 
than two billion dollars. ${ }^{6}$ Murdoch did become a U.S. citizen, and the sale of the stations was cleared after an FCC hearing. And so, the Fox Broadcasting Network was born.

At first, the new network was hardly noticed. ${ }^{7}$ Since then, it has risen to give the Big Three serious competition. ${ }^{8}$ In addition to an increased share of the market, Fox was able to capture the right to televise National Football League games from CBS. ${ }^{9}$ But it wasn't until the summer of 1994 that Fox was able to draw such widespread attention to itself.

\section{B. The Network Grows Up}

On the eve of its second decade, Fox's troubles began in May, 1994 when it unveiled plans to invest in twelve new stations in conjunction with another communications group, New World Communications Group, Inc. ${ }^{10}$ These new stations ${ }^{11}$ were former Big Three affiliates that would become Fox affiliates. As reported in the May 25, 1994, Wall Street Journal:

In its seven years of existence, Fox Broadcasting Co. has been called a 'weblet' by the trade paper Variety while CBS, ABC, and NBC have been referred to as 'webs.'

Now the weblet seems about to grow up.

With new investments in a TV station group alliance and National

6. Id.

7. "Fox was a non-entity in 1987-88, when it averaged a 3.7 rating while the Big Three had a 43 rating and a $71 \%$ share of the audience. Since that season, Fox ... [has] chipped away to the point that midway through the 1994-95 season, ABC, CBS, and NBC have a 38.8 rating and 58\% share." Steven Battaglio, Big Three Brave Crowded New World, HoulYwoOd REP., Jan. 5,1995 , at 1,46 .

8. Id..

9. Having bid $\$ 1.56$ billion for the games in December of 1993, Murdoch himself attributes Fox's biggest successes to this. When asked if he thought Fox had finally come to be head-to-head with the Big Three, he responded, "Yes, I think that's true. They've all got their different philosophies and different ways, but we certainly see ourselves broadening to there being four real networks. And nothing has contributed to that more than the football." Alex Ben Block and Robert Dowling, Murdoch: Fox Head-to-Head with Big Three, Hollywoon REP., Jan. 10 , 1995, at 1, 13.

10. Elizabeth Jensen and Mary Lu Carnevale, Fox Proves It's Ready to Play in the Big Leagues, WALL ST. J., May 25, 1994, at B1.

11. The twelve stations, owned by New World, and being switched to a Fox affiliate included: WJBK (Detroit); WAGA (Atlanta); WJW (Cleveland); WTVT (Tampa); WITI (Milwaukee); KSAZ (Phoenix); WDAF (Kansas City); WGHP (High Point-Greensboro); WBRC (Birmingham); KDFW (Dallas); KTVI (St. Louis); and KTBC (Austin). For a report card look at how these new stations have done as Fox affiliates see Joe Flint, Fox Pups Show Growth, VARIETY, Dec. 18, 1994, at 92. 
Football League broadcast rights, Rupert Murdoch, chairman of Fox's parent, News Corp., is making a $\$ 2$ billion bid to catapult Fox into the big-time ranks of its three network rivals. ... [I]ts latest moves make it a formidable contender to fight the other networks on the most important turf: prime-time and sports programming. ${ }^{12}$

While the other networks had previously grumbled about certain benefits that Fox had received from the FCC in the past, Fox's latest action caused them to shout. As an upstart network, Fox does indeed enjoy certain advantages over the Big Three. Principally, as Fox is limited to fifteen hours of prime time as compared to NBC's, CBS's and ABC's 22 hours, Fox is permanently exempted from the major Prime Time Access Rule imposed upon the other networks. ${ }^{13}$ Similarly, Fox is not restrained by the Fin-Syn regulations imposed on the Big Three. ${ }^{14}$

The first real challenge to Fox's ownership, however, came not from the Big Three, but rather from the National Association for the Advancement of Colored People (NAACP). ${ }^{15}$ Citing several instances, David Honig, a Washington lawyer representing the Metropolitan Council of the NAACP, accused Fox of failing to report to the FCC Fox's ownership structure. ${ }^{16}$ The NAACP's position in supporting the current FCC regulations restricting foreign ownership ${ }^{17}$ stems from the desire to increase minority ownership of broadcast stations. "As it is, it is hard for minorities to bid against domestic capital, and it will be even harder for them to bid against foreign capital."18

12. Id. News Corporation is a corporation based in Sydney, Australia. It owns a $99 \%$ equity interest in Twentieth Holdings. See infra text accompanying note 20.

13. Briefly, the Prime Time Access Rule (PTAR) prohibits the network affiliates in the 50 largest cities from airing network reruns during the 7:00 p.m. to 8:00 p.m. time slot. Earlier this year, the FCC met to discuss the elimination of the PTAR within the next year. Brooks Boliek, FCC Primed To Phase Out Prime Time Access Rule, HoLLYwOOD REP., July 28-30, 1995 , at 1 .

14. Fin-Syn, or financial (distribution) regulations and syndication regulations prohibit the Big Three from financing or distributing to local television stations directly and from competing in the domestic program syndication business, respectively. Two years ago, the FCC rewrote the fin-syn rules, allowing networks to own a financial interest in programming. All other prohibitions were to expire within two years (i.e., by November 1995). See Steve Brennan, Sudden Sunset for Fin-Syn, HOLLYWOD REP., Sept. 7, 1995, at 1.

15. Jensen and Camevale, supra note 10 , at B1. The initial challenge from the NAACP came in the fall of 1993 as Fox attempted to buy WGBS-TV in Philadelphia. Christopher Stern and Steve McClellan, Foreign Ownership Waiver Likely For Fox, BROADCASTING AND CABLE, May 8, 1995, at 16.

16. Id. "This is the fourth or fifth time the commission has tried to get this information out of them, and it is unfortunate that it still is not fully disclosed."

17. See infra note 52 and accompanying text.

18. Jensen and Camevale, supra note 10 at $\mathrm{B} 1$ (quoting attomey David Honig). 
In June of 1994, New York branches of the NAACP, with the backing of Representatives Cardise Collins ${ }^{19}$ and Edolphus Towns (D., N.Y.), filed papers with the FCC contesting Fox's ownership of nine TV station licenses. ${ }^{20}$ The NAACP called for a "full-blown hearing" into the ownership and financing of Fox. In its letter, the NAACP argued that Fox was controlled by the Sydney-based News Corporation, ${ }^{21}$ in violation of the FCC's restrictions on foreign ownership of broadcast stations. Furthermore, Fox had selectively made limited disclosures about its financing and ownership when originally applying for its license in 1985..$^{22}$

In a response letter to the FCC amid these allegations, Fox denied that it had made limited disclosures and further claimed that Fox was in compliance with all FCC regulations:

Fox lawyers said that News Corp. has an 'indirect approximately 99\% economic/equity interest' in Twentieth Holdings, Fox Television Stations' parent. Rupert Murdoch, who became a U.S. citizen in order to buy the stations in 1985 , owns stock that represents $76 \%$ of the voting rights of Fox Television; the remaining $24 \%$ is held by News Corp., which Fox lawyers say is controlled by Mr. Murdoch. Moreover, they say, Fox disclosed in 1985 that News Corp. would supply most of the funds to acquire the Metromedia Inc. stations that formed the core of the Fox network. ${ }^{23}$

\section{The Champion, NBC, Enters the Ring}

Fox's problems began to snowball in late fall of 1994. At the same time it was closing its deal with New World Communication, it was courting television stations in Philadelphia, Boston, and Green Bay. Through a joint venture with Savoy Pictures, Inc., Fox established SF Broadcasting, the objective being to buy $\mathrm{NBC}, \mathrm{CBS}$, and $\mathrm{ABC}$ affiliates and convert them to Fox affiliates. ${ }^{24} \mathrm{Up}$ to this

19. At the time, Rep. Collins was a member of the Energy and Commerce Committee and Chairperson of the Consumer Protection Subcommittee. Rep. Collins' involvement in the controversy centered around a letter urging a congressional hearing while Rep. Towns' involvement comes in a protest against Fox for canceling the show "Roc," a show depicting a working-class African-American family in Baltimore.

20. Mary Lu Carnevale, Control of Fox TV Sparks Controversy on Capitol Hill and Calls for Hearing, WALL ST. J., June 13, 1994, at B8.

21. See supra note 11.

22. Carncvale, supra note 20.

23. Id.

24. Dennis Wharton and Joe Flint, NBC Slams Fox's Bids, VARIETY, Nov. 28, 1994 at 108. Ironically enough, the article appears directly above a quarter-page, full-color advertisement for Fox's programming. 
point, NBC had been successful in attempting to block SF Broadcasting's purchase of WLUK in Green Bay, Wisconsin. But in November of 1994, the FCC announced that it would accept SF Broadcasting's application. Upon receipt of this announcement, NBC intensified its attacks on Fox's ownership. Joining the NAACP in the ring, NBC filed its petition on November $30,1994,{ }^{25}$ arguing that Fox had "blatantly" violated the foreign ownership restriction rules of the FCC. ${ }^{26}$ This time, Fox lashed back at the Big One. "NBC is simply using the FCC to thwart competition in the marketplace and that is wrong ... [Fox] could take out a catalogue of fraud convictions against NBC parent General Electric, but then we'd be no better than they are."27 Thus, the stage was set for a 90's version of the "Network Battle of the Stars," Hard Copy style. ${ }^{28}$

Shortly after the fireworks began, the FCC issued a gag order on the whole ordeal. ${ }^{29}$ This drew criticism from within, without, and everywhere else. The gag order was initially imposed to prevent officials with the NAACP from discussing the issue with the public. Almost immediately, the American Society of Newspaper Editors blasted the FCC in a protest letter. ${ }^{30}$ On December 15, the

25. Brooks Boliek, NBC Charge Foreign to Fox, HoLLYwood REP., Dec. 1, 1994, at 1.

26. NBC additionally argued that Fox was attempting to skirt the FCC restriction which bars a single entity from owning more than 12 television stations nationally. 47 C.F.R. U.S.C. 73.3555 (1995). Under this rule, a company is considered the owner of a station if it has more than a five percent share of the voting stock. Fox already owned 10 stations, the stations in Philadelphia and Boston would make 12, and if the FCC was to find that Fox had an attributable interest (i.e. five percent voting interest) in the four SF Broadcasting stations, this would make sixteen, in violation of the ownership restrictions. Fox seems to argue that the televisions stations are under the domestic control of SF Broadcasting and New World Communications. Such domestic control would insulate it from having an attributable interest in the stations.

27. Wharton and Flint, supra note 24 at 108.

28. In one instance, Mr. Murdoch wrote to the FCC urging it to decide whether Fox was an American or foreign corporation, emphasizing his own "personal anguish" over the matter. In what has become typical corporate manner, NBC responded, writing, "It is certainly not clear why complying with the law should cause anyone 'anguish' -. unless they are not accustomed to complying with the law." Boliek, supra note 25.

29. Issued on December 7, 1994, the gag order was reported as follows:

WASHINGTON -- In what may be an unprecedented action, the FCC slapped a gag order on officials and documents involved in a critical portion of the agency's investigation into Fox's ownership... . The gag order goes beyond what is usually termed a "restricted proceeding" in which FCC officials are forbidden to discuss a particular issue with the public. It not only applies to FCC officials, but also to parties in the case and puts new documents related to the issue under lock and key until after the commission decides the issue.

Brent Boliek, FCC Imposes Gag Order on Fox Ownership Debate, Hollywood REP., Dec. 8, 1994 at 1.

30. "The commission's decision to cloak in secrecy the inquiry and the proceedings concerning the dispute between NBC and Fox Television Stations Inc. is a gross violation of the public trust invested in the FCC." Lisa de Moraes, Editors Oppose FCC Gag Order, HourwooD REP., Dec. 14, 1994, at 4, 8 (quoting ASNE president Gregory Favre). 
NAACP filed papers with the FCC accusing the commission of violating its First Amendment right of free speech by imposing the gag order. ${ }^{31}$

Criticism didn't stop there; it came from within the FCC as well as from the floor of Congress. The new chairperson of the Senate Commerce Committee lashed out against the FCC on its conduct concerning its probe of the issue. In a letter to the FCC chairperson Reed Hundt, Senator Larry Pressler (R., S.D.) criticized the FCC's gag order, saying that it represented "a serious lack of forethought and sensitivity to First Amendment rights." ${ }^{32}$ Pressler's letter not only criticized the gag order, but indicated that political forces were behind the issue as well. "It appears on the surface that there was an orchestrated, partisan campaign that had nothing to do with the real issue facing U.S. businesses competing overseas who are facing barriers because of our outdated foreign ownership restrictions." 33 Similarly, FCC commissioner James Quello criticized the commission's handling of the probe. In a letter to Sen. Pressler, Quello questioned a "series of unusual staff decisions" that gave the appearance of a "star chamber" investigation. ${ }^{35}$ Eventually, the FCC had to relax its gag order in light of the overwhelming criticism. ${ }^{36}$

\section{The Book Deal Gone Bad}

Unfortunately, things only got worse for Fox. Newly-elected Speaker of the House, Newt Gingrich (R., Ga) had a story to sell, and HarperCollins bought, giving Newt a $\$ 4.5$ million advance. ${ }^{37}$ The deal was scrutinized before the ink was even dry on the contract. HarperCollins is owned by News Corporation, the

31. Brooks Boliek, NAACP: Revoke Fox Gag Order, FCC Filing Seen as First Step Toward Getting the Issue Into Courts, Hourwoon REP., Dec. 16-18, 1994, at 3.

32. Brooks Boliek, GOP's Pressler Lashes FCC on Probe of Fox, HoL YwoOD REP., Dec. 28, 1994, at 1, 2.

33. Id Murdoch is not a stranger in Washington. In the late 1980's, he drew the attention of Sen. Ted Kennedy, whom Murdoch's papers regularly skewered. Kennedy waged a personal vendetta against Murdoch with the help of Sen. Ernest Hollings and was successful in forcing Murdoch to sell Alexander Hamilton's New York Post. Kennedy would later boast of having killed the Post, the nation's oldest newspaper. See generally, Kennedy's Boast, WaLL ST. J., Jan. 6, 1988, at A14; Ted Kennedy Killed the Post, WALL ST. J., Mar. 17, 1993, at A14.

34. The FCC has five commissioners appointed for terms of five years and a chairperson appointed by the President. 47 U.S.C. \$154(c); Pub. L. No. 99-334 (1986).

35. Dennis Wharton, Fox Probe Stirs Talk, VARIETY, Jan. 9-15, 1995, at 84.

36. Brooks Boliek, FCC Relaxes Gag Order in Fox Ownership Debate, HoulYwood REP., Dec. 22, 1994, at 4.

37. Phil Kuntz and Jeffrey A. Trachtenberg, Democrats Criticize Gingrich Book Deal with Murdoch From Amid FCC Dispute; WALL ST. J., Dec. 23, 1994, at A12. Gingrich's book advance was second only to Ronald Reagan's seven million dollar advance in terms of book dealings with political leaders. In the end, Gringrich would refuse the hefty advance and settle for a $\$ 1$ advance plus royalties to quiet the controversy. Panel Queries Murdoch on Gingrich Book Deal, HoulYwOOD REP., Aug. 2, 1995, at 7. 
same News Corporation that owns Twentieth Holdings, the parent of Fox Television Stations, Inc., all under the watchful eye of Rupert Murdoch. It was later revealed that Gingrich and Murdoch had met behind closed doors in late November. ${ }^{38}$ However, both parties maintained that the book deal was not discussed as Murdoch was unaware of it. ${ }^{39}$ While Gingrich was dealing with criticism from the Democrats, ${ }^{40}$ Fox had to deal with new allegations brought by the NAACP. Based upon this most recent event, the NAACP filed papers with the FCC asking it to include the book deal in its ongoing investigation of the foreign ownership issue. Attorney David Honig wrote in his letter to the FCC, "As the book deal raises at least an appearance of impropriety, we believe it would be appropriate for the commission to inquire whether officials of Fox played any role in the HarperCollins negotiations." ${ }^{21}$ This new charge brought Fox's "character" into question and added further potentially threatening material to the FCC's probe of Fox.

By January of 1995, industry analysts had begun offering opinions. Most experts agreed it was unlikely that Fox would have its licenses revoked. ${ }^{42}$ More likely, if it was found that Fox was foreign-owned, an expensive restructuring process would have to be undertaken, a process that would surely set the up-and-coming network back some. And what of $\mathrm{NBC} ?^{43} \mathrm{NBC}$ was clearly in

38. Phil Kuntz, Murdoch Lobbyist Explains Meeting with Gingrich, WALL ST. J., Jan. 16, 1995, at A4.

39. Id.

40. Gingrich suffered from the incident as evidenced by the blow-up occurring on the floor of the House on January 18. In a Wall Street Journal/NBC poll, when asked who better represents the values of the Republican party, $60 \%$ of those Republicans polled named Senator Robert Dole as opposed to $24 \%$ for Rep. Gingrich. Eyeing Newt, WALL ST. J., Jan. 19, 1995, at Al.

41. Brooks Boliek, NAACP Seeks FCC Probe of Fox Book Deal, HOLLYwOOD REP., Jan. 4,1995 , at 1,41 .

42. Dennis Wharton and Joe Flint, FCC Unlikely to Revoke Fox TV Licenses, VARIETY, Dec. 12-18, 1994, at 31. Admittedly, the worst-case scenario would be for the FCC to find that Murdoch had not made full disclosure and that Fox had violated the $25 \%$ rule imposed by 47 U.S.C. $\$ 310$ (b). This is something the FCC has not done in over a decade (when it revoked RKO's licenses). Most every observer agrees that this will not happen: D.C. observers say such a finding is unlikely, in part because the FCC would be admitting it screwed up the original Fox investigation in 1985. "The FCC risks some embarrassment here for not having looked into this more closely the last time," says Craig Blakely, a D.C. communications attorney. Id.

43. Some (generally Fox supporters) have speculated that NBC originally joined the action because it was trying to eliminate competition from Fox. This would not be a novel use of the Commission's power. "[T]he biggest defenders of the F.C.C. may be in the industry, where companies routinely use Federal Regulation to seek advantage or to trounce rivals." Edmund L. Andrews, N. Y. TIMEs, May 31, 1995, at D4. One recent Fox letter stated:

Since NBC is widely reported to be for sale, and assuming a pricing multiple of 10 times cash flow, our aggressive competition may have cost NBC's parent (General Electric) $\$ 1$ billion in the price of any contemplated sale ... It's no wonder that NBC has been all over the FCC and Capitol Hill seeking to make trouble for Fox. 
a win-win situation. Obviously, if sanctions were taken against Fox, NBC would be successful in eliminating some of the recent competition that has affected it and the other networks. If the FCC ultimately adjudged Fox Television Stations, Inc. to be American owned, NBC would likely still win. At the time, it was widely rumored that General Electric was offering NBC up for sale. ${ }^{44}$ Though NBC's domestic value might decrease if the FCC finds for Rupert Murdoch, its foreign value would increase. As David Londoner ${ }^{45}$ wrote, "[I]t's even better for them (NBC) if they lose, because it opens the door wider to foreign companies. Everybody thinks its just the Japanese who would be interested -- the Sonys and the Matsushitas. But you can't count out European giants, like Bertelsmann." ${ }^{146}$

Meanwhile, the NAACP appeared as though it was already enjoying some limited success from its efforts against Fox. In October of 1994, Fox announced plans to join with yet another company in an effort to convert affiliates. This time, Fox joined with Silver King Communications, Inc. to form Blackstar Communications, L.L.C., its chairman to be John Oxendine, an African-American broadcaster. ${ }^{47}$

While all these involvements are fascinating and perhaps may someday be made into a made-for-TV "Movie of the Week," it is the underlying legal ramifications which are of more importance. The NBC-Fox battle is not the first time that the FCC's foreign ownership regulations have come into question. But when one begins to speak of NAFTA and GATT, the general public begins to lose interest and change the channel.

\section{FCC RESTRICTIONS ON FOREIGN OWNERSHIP}

\section{A. German Invaders and Section 310(b)}

The world today is truly becoming a global village. Perhaps no other area offers as much evidence of this as the field of telecommunications. As technological breakthroughs have led to instantaneous access to nearly any spot on the globe, one problem which has arisen is alien ownership and investment in

Brooks Boliek, Fox Looks to Stick It to NBC With Bumper Stickers, HoLLYWOOD REP., Dec. 20, 1994, at 1, 70. The same article detailed Fox's attempt to persuade congressional attitudes by sending House members and Senators bumper stickers which read "Fox. Competition. Deal With It!" and "FOX - It's Competition Stupid!" (Whether this refers to NBC executives or Congressional members is uncertain).

44. Id.

45. Managing Director of the investment house Werthiem Schroder.

46. J. Max Robins and Joe Flint, How Foreign is Fox?, VARIETY, Dec. 5-11, 1994, at 1, 85.

47. Elizabeth Jensen, Fox to Invest In Station Group Owned by Blacks, WALL ST. J., Oct. 10, 1994, at A4. 
domestic businesses. ${ }^{48}$ Its seems as though one cannot turn around without encountering foreign-owned "American" icons. Foreign investment and ownership has sparked great debate over whether the merits outweigh the risks involved. ${ }^{49}$

One area which has been relatively free of foreign ownership is the broadcast industry. As evidenced by the NBC-Fox struggle, this long-standing immunity has come under fire. ${ }^{50}$ Many have questioned the rationality of the FCC's current legislation that has remained virtually unchanged since its adoption in 1934..$^{51} 47$ U.S.C. $\S 310(b)$ deals with alien investment and ownership as it appears in the context of broadcasting properties. ${ }^{52}$

Foreign ownership restrictions find their origination in the Radio Act of $1927,,^{53}$ and before that, the Radio Act of $1912^{54}$ The adoption of these regulations stemmed from the fear that a foreign-controlled radio station could seriously jeopardize national security interests through the interference with American broadcast. ${ }^{55}$ Similarly, in 1927, the legislation was justified as German telegraph operators were able to give advance warning to German boats waiting off the East Coast of the United States concerning American activities. ${ }^{56}$ To

48. Christopher F. Corr, A Survey of United States Controls on Foreign Investment and Operations: How Much is Enough? 8 AM. U. J. INT'L L. \& POL'Y 417, 417 (1994).

49. Id.

50. For example, both the recent North American Free Trade Agreements (NAFTA) as well as the recently adopted General Agreement on Tariffs and Trade have contained exclusionary language concerning the entertainment industry, drawing criticism from not only those in the entertainment industry but the government as well.

51. The Communications Act of 1934, Title 47 of U.S.C. For instance, in a column found in the June 9, 1994 edition of the Wall Street Journal at A14, Bob Wright, president of NBC wrote the following:

While the affiliate shuffle means Fox will compete more vigorously in the marketplace, we at NBC have no desire to rein in Fox through government regulation. Instead, the original broadcast networks, and broadcast stations across the country, should be set free from outdated government restrictions that apply only to our industry and thus discriminate against us as we increasingly compete with cable, telephone and other entities.

52. 47 U.S.C. \& 310(b); Pub. L. No. 103-354 (1995).

53. Radio Act of 1927 , Ch. 169, $\$ 39,44$ Stat. 1162 (1928).

54. An Act to Regulate Radio Communication, Pub.L.No. 62-264, 37 Stat. 302 (1912).

55. Stephan R. Konigsberg, Think Globally, Act Locally: North American Free Trade, Canadian Cultural Industry Exemption, and the Liberalization of the Broadcast Ownership Laws, 12 CARDOZO ARTS \& ENT. L.J. 281, 316 (1994). The original 1912 Act only required the licensee to be an American citizen or corporation. However, the need for tighter restriction would soon be recognized as two German nationals applied for a radio station license in Long Island. The Germans were allowed the license as they had applied in the name of a U.S. corporation. Ian M. Rose, Barring Foreigners From Our Airwaves: An Anachronistic Pothole On the Global Information Highway, 95 CoLUM. L. REV. 1188,1194 (1995).

56. Patricia Diaz Dennis, Panel Discussion: Telecommunications in a Global Market, II B.U. INT'L L.J. 153 (1993). 
ensure that this would never happen again, Congress included the foreign ownership restrictions in 1927 and again in $1934 .{ }^{57}$

\section{B. Section 310(b) Today}

Section 310(b) provides the following:

License ownership restrictions

(b) Grant to or holding by alien or representative, foreign corporation, etc.

No broadcast or common carrier or aeronautical en route or aeronautical fixed radio station license shall be granted to or held by $--$

(1) any alien or the representative of any alien;

(2) any corporation organized under the laws of any foreign government.

(3) any corporation of which any officer or director is an alien or of which more than one-fifth of the capital stock is owned of record or voted by aliens or their representatives, or by a foreign government or representative thereof or by any corporation organized under the laws of a foreign country;

(4) any corporation directly or indirectly controlled by any other corporation of which any officer or more than one-fourth of the directors are aliens, or of which more than one-fourth of the capital stock is owned of record or voted by aliens, their representatives, or by a foreign government or representative thereof, or by any corporation organized under the laws of a foreign country, if the Commission finds that the public interest will be served by the refusal or revocation of such license..$^{58}$

Sections $310(b)(1)$ and 310(b)(2) bar foreigners or foreign corporations from owning broadcasting licenses in the United States. Sections 310(b)(3) and 310 (b)(4) restrict the amount of ownership that a foreigner may have in domestic corporations having licenses. Section $310(\mathrm{~b})(3)$ applies to individuals or corporations that have a direct interest in a domestic corporation licensee. Of these types of corporations, a foreigner may only have up to twenty percent of capital or voting stock. Section $310(b)(4)$ applies to foreign holding corporations of domestic corporations. This paragraph was added to prevent foreign-controlled parent companies from circumventing the rules by creating

57. For a more complete analysis of the legislative history of $\$ 310(\mathrm{~b})$, see Watkins, Alien Ownership and the Communications Act, 33 FED.COMM. L.J. 1 (1981).

58. 47 U.S.C. \$ 310(b); Pub. L. No. 103-354 (1995). 
domestically wholly-owned subsidiaries able to hold broadcast licenses. ${ }^{59}$ Such a holding company is limited to a twenty-five percent share of the capital or voting stock, either directly or indirectly. Finally, Section 310(b)(4) provides an "out-clause": the Commission may refuse or revoke a license if it finds that the public interest will be best served by such refusal. Stating this conversely, the Commission may waive the foreign ownership restrictions if it finds the public interest to be served by such waiver. In the past, this "out-clause" has been exercised stringently. ${ }^{60}$

\section{Public Interest under Section 310(b)(4)}

Although Sections 310(b)(3) and 310(b)(4) seem nearly identical, they are different in several respects. A careful analysis of the differences indicates that by careful structuring, a foreigner can own a significant amount of broadcast properties without violating the FCC's regulations. ${ }^{61}$ As pointed out above, Section 310(b)(3) deals with direct ownership interest in the broadcast license, limiting it to $20 \%$, whereas Section 310 (b)(4) limits to $25 \%$ the amount of ownership in companies directly or indirectly "controlling" the licensee. ${ }^{62}$ More importantly, Section 310 (b)(4) grants the FCC discretion in determining public interest while the other paragraphs of Section 310(b) lack such language.

Through a series of decisions, the FCC has developed various factors to be considered in making a public interest determination. ${ }^{63}$ The following factors were enunciated by the FCC following a 1987 Notice of Inquiry and Rulemaking: ${ }^{64}(1)$ whether the alien's country of citizenship enjoys close and friendly relations with the United States; (2) the extent of foreign ownership or control of the corporation (i.e., majority versus minority shares); (3) whether the

59. Konigsberg, supra note 55, at 305 n. 155 .

60. Diaz, supra note 56 , at 155 . Ms. Dennis notes that a recommendation by the National Telecommunications and Information Administration (a division of the Department of Commerce), has been for the FCC to apply this clause less stringently so as to allow for more direct foreign investment. Prior to the Fox investigation, there has only been one instance where the FCC has waived the foreign ownership rules in the public interest, and then only when the foreign corporation was subject to several restrictions. See Banque de Paris et des Pays Bas, 6 F.C.C.2d 418 (1966). This public interest waiver would be crucial in determining the fate of Murdoch and News Corp.

61. See generally Ronald W. Gavillet, et al., Structuring Foreign Investments in FCC Licensees under Section 31O(b) of the Communications Act, 27 CAL. W. L. REV. 7, 38 (1990). For instance, the authors suggest that through a direct $20 \%$ ownership position in a licensce along with a $25 \%$ interest in the domestic holding company that owns the remaining $80 \%$, a foreigner could own up to a $40 \%$ interest in a licensee.

62. For the purposes on Section $310(\mathrm{~b})(4)$, a controlling interest is a majority (50\% or more) interest in a licensee, $l d$. at 10 .

63. See e.g., GRC Cablevision, 47 F.C.C.2d 487; PrimeMedia, 3 F.C.C.Rcd. 4293.

64. Gavillet et al., supra note 61 , at 17. 
licensed facility involved is passive in nature; and (4) the qualifications of the applicant.

\section{Case Law Interpreting Section 310(b)}

The FCC is granted broad discretion in applying Section $310(\mathrm{~b})$ and only rarely does a case come before the Court of Appeals. One such instance involving foreign ownership where an appeal was granted was in Telemundo, Inc. v. Federal Communications Commission. ${ }^{65}$ In that case, the plaintiffs were among three groups petitioning the FCC to block the sale of two defunct Puerto Rican television stations to the Television Broadcasting Corporation ("TBC"). Telemundo argued, inter alia, that the corporate structure of TBC would result in violations of Section 310(b)(4). Specifically, they argued that despite statutory compliance, de facto control of TBC would remain in the hands of aliens. The Mass Media Bureau ("the Bureau") of the FCC had initially determined that the structure would indeed violate Section 310(b)(4) as foreign ownership was above the $25 \%$ limit and that control of the station was in the hands of Venezuelan nationals. ${ }^{66}$ However, the Bureau permitted TBC to amend its application, which it did, bringing the aggregate foreign ownership below $25 \%$ and giving $100 \%$ control to American citizens. ${ }^{67}$ Quoting the Commission, the court stated:

TBC has satisfactorily readjusted its alien ownership to comply with the statutory standard. Additionally, TBC has voided the questioned agreements and has, in fact, retained American citizens to provide the management services that were the subject matter of the voided contracts. ${ }^{68}$

In upholding the decision of the FCC, the court held, "[w]e see no reason to conclude that the Commission acted improperly or otherwise abused its broad discretion in finding that the problem of alien control had been satisfactorily resolved."69

While initial justification for Section 310 (b) came in the form of national security interests, this could hardly be argued today. At best, it could be argued

65. 802 F.2d 513 (D.C. Cir. 1986).

66. Id. at 515.

67. Id.

68. Id. at 515-16 (quoting In re Zaida Perez Vda. de Perez Perry, et al. and Television Broadcasting Corp., F.C.C. 85-381 (July 26, 1985), J.A. at 206).

69. Id. at 516. The court also cites two other cases in which the FCC determined that statutory compliance with Section 310(b)(4) was not the same as actual practice. See Channel 31, Debtor-in-Possession, 45 R.R.2d (P \& F) 420 (1979) (Canadian de facto control of corporation was in question); Spanish International Communications Corp., 48 Fed. Reg. 28,549 (June 16. 1983). 
that since some sixty percent of the viewing audience's attention is commanded by only three stations, foreign ownership should still be restricted. ${ }^{70}$ More likely, there is some other reason for maintaining the sixty year-old regulations in a rapidly changing world. Indeed, an analysis of the United States' trading partners sheds some light on the existence of Section 310(b).

\section{E. Other Countries Attempts to Ward off Foreign Invaders}

The United States is not alone in its protection of ownership of broadcast properties. Canada ${ }^{71}$ and France ${ }^{72}$ have similar protective provisions. The list of examples does not stop there. In Australia, Rupert Murdoch and his News Corporation have difficulties obtaining television stations because the News Corporation is considered an American entity and, therefore, in violation of Australia's restrictive $15 \%$ limit. Likewise, in Asia Murdoch's efforts in a joint venture with Telstra Corp were frustrated by foreign ownership restrictions. ${ }^{73}$ There are some countries however, that do not restrict their foreign ownership of broadcast properties, such as the United Kingdom. ${ }^{74}$

\section{NAFTA, GATT, CUltural PRotectionism, AND How Section 310(B) HURT THE AMERICAN BROADCASTING INDUSTRY}

\section{A. Canada's Cultural Industry Exclusion Clause}

The North American Free Trade Agreement (NAFTA) was passed on November 20, 1993. This agreement was designed to create a free North American trade zone, effecting six trillion dollars of trade among the populations of its member-countries, the United States, Canada, and Mexico. ${ }^{75}$ NAFTA was not the first bilateral trade agreement. On January 1, 1989, the Free Trade Agreement (FTA) between the United States and Canada went into effect. Both NAFTA and FTA were the result of lengthy, precarious negotiations which seemed to be constantly on the brink of falling apart.

Few Americans realize the effect their culture has on those outside their borders. However, many Canadians, searching for a culture of their own, are

70. See Battaglio, supra note 7 , at 46 .

71. Peggy Berkowitz, Hushed Voices: Canada Tries To Foster Its Culture By Limiting U.S. Media Influences, WALL. ST. J., Aug. 12, 1986, at 1.

72. Thomas Kamm, France Will Limit Foreign Ownership in Telecommunications Firm to $20 \%$, WALL. ST. J., Dec. 2, 1988 , at 1 . 21, 1993.

73. News Corp. Planning Venture With Telstra in Asia-Pacific Region, WALL ST. J., July

74. Richard L. Hudson, Britain Urges Telecommunications Field to Be Opened to Many Local, Foreign Firms, WALL ST. J., Nov. 14, 1990, at A12.

75. Konigsberg, supra note 55, at 281. 
painfully aware of the effect of the American culture. The fear of American cultural domination is very real for Canadians. ${ }^{76}$ "Canada is carpet-bombed daily by American culture and entertainment. Occasionally, it bridles under the onslaught. This periodic expression of defiance known here as 'cultural nationalism' is stirring again." It was this "cultural nationalism" that led to the Canadian insistence on the inclusion of the Cultural Industry Exemption Clause (Exemption Clause). ${ }^{78}$ In addition to the Exemption Clause's inclusion, the Canadians refused to even discuss the possibility of its repeal.

The Exemption Clause represents an obvious barrier to free trade. Yet the clause again found its way into NAFTA when the Canadians refused to negotiate its omission. ${ }^{79}$ Unfortunately, NAFTA goes one-step further than did FTA. Under NAFTA, the exclusionary clause has been expanded to include intellectual property rights. "This means that, although intellectual property is given substantial protection under the [sic] NAFTA, films, television programs, home videos, books, and sound recordings have no protection in Canada and are removed from those binding commitments of NAFTA's chapters on intellectual property." 80

The clause immediately following this exemption appears to nullify the exemption at least partially. This clause allows a NAFTA party to "take 'measures of equivalent economic effect' in response to any actions that would

76. A great example for anyone with a dry sense of humor is cited in Konigsberg's article:

[A]s a relatively benign illustration of how American televison can undermine the constitutional style of another country, Canadians through the 1970s saw one American police drama after another in which officers read Miranda wamings to criminals as they were apprehended, including "you have the right to remain silent, you have the right to counsel." Despite their different constitutional and political system, which had no explicit bill of rights, a great number of Canadians apparently believed that they had the "right to keep silent, the right to counsel, and so forth."

Konigsberg, supra note 55 at 296 n. 106 (citing George H. Quester, The International Politics of Television 109-110 (1990)).

77. Charles Trueheart, Culture Clash: Canadian Nationalists Decry American Infiltration, WASH. POST, Dec. 2, 1994, at A34.

78. Konigsberg, supra note 55, at 284 (citing U.S.-Canada Free Trade Implementation Act of 1988, Pub.L.No. 100-449, 102 Stat. 1851 (1988), art. 2005(1)). ("Cultural industries are exempt from the provisions of this Agreement, except as specifically provided in Article 401 (Tariff Elimination), paragraph 4 of Article 1607 (divestiture of an indirect acquisition) and Articles 2006 (Retransmission. Rights) and 2007 (Print-In-Canada Requirement) of this Chapter."). An example of the exemption clause in action is seen in the recent controversy between American-based Country Music Television (CMT) and Canada's new country-music channel. Ten years ago, CMT helped foster a boom in Canadian country music. Now the new Canadian-based country-music channel trumped its competitor, forcing it off the air. See generally, Truehart, supra note 77; and Etan Viessing, CMT Invokes NAFTA In Protest, HOLLYwOOD REP., Dec. 23-25, 1994, at 3. (citing Section 301 of NAFTA).

79. Konigsberg, supra note 55 , at 284.

80. Id. at 299. 
be considered inconsistent with the trade agreement were it not for the cultural exemption." ${ }^{\text {"1 }}$

The objectives of NAFTA appear relatively simple. ${ }^{82}$ However, NAFTA falls short of these objectives when considering the broadcast industry. In addition to the United States' restrictions imposed by Section 310(b) for broadcast television systems, under NAFTA, the United States reserves the right to impose "equivalent treatment" on any person whose nation limits U.S. ownership of a cable television system as well as reservation concerning "investment in, or the provision of basic telecommunications networks and services. ${ }^{183}$ Canada makes similar reservations. ${ }^{84}$ Finally, Mexico restricts foreign ownership of television systems and reserves the right "to adopt or maintain any measure regarding virtually every aspect of its basic telecommunications network." 85

\section{B. The EC's Green Paper}

"Cultural nationalism" is not to be found in Canada and Mexico alone. In June of 1984, the European Community (EC) Commission released its "Television Without Frontiers" Green Paper (Green Paper), which was to become the backbone of the infamous "Television Without Frontiers" Directive of 1989. ${ }^{86}$ The Green Paper called for the relaxation of borders within the EC while recognizing the need to protect European culture from invasion. ${ }^{87}$ Europeans

81. Panel Urges Canada to Push for Codes Covering Subsidies, Dumping in NAFTA, BNA INTL. TRADE DAILY, Nov. 17, 1994.

82. North American Free Trade Agreement, December 17, 1993, U.S.-Can.-Mex., PubL.No. 103-182, 107 Stat. 2057, reprinted in 32 1.L.M. 605 (1993) [hereinafter NAFTA], The preamble of NAFTA states:

The Government of Canada, the Government of the United Mexican States, and the Government of the United States of America Resolve to;

STRENGTHEN the special bonds of friendship and cooperation among their nations;

CONTRIBUTE to the harmonious development and expansion of world trade and provide a catalyst to broader international cooperation ....

FOSTER creativity and innovation, and promote trade in goods and services that are the subject of intellectual property rights.

83. Exploding Goods and Services Under NAFTA, Mexico Trade and Law Rep., Oct. 1, 1994 available in Westlaw, World Library.

84. Id.

85. Id.

86. Konigsberg, supra note 55, at 300.

87. The objectives of the Green Paper were:

to demonstrate the importance of broadcasting (radio and television) for European integration and, in particular, for the free democratic structure of the European Communities; to illustrate the significance of the European Economic Community (EEC Treaty) for thase responsible for producing, broadcasting, and 
drew justification for the move from a similar fear of American cultural domination.

The "Television Without Frontiers" Directive received immediate reaction from the American entertainment industry. The United States industry was being shut out of Europe while the internal borders were coming down. Jack Valenti, President of the Motion Picture Association of America, questioned whether "[t]he culture of any European [is] so flimsily anchored, so tenuously rooted, that European consumers and viewers must be caged and blinded else their links with the historic and distinguished past suddenly vanish?'88

The European Community was not without further justification for its protectionist attitude not only towards broadcast property ownership but also programming to be shown on European television sets. ${ }^{89}$ To be sure, "[t]he Community further justifies its zealous position by identifying measures within the U.S. legal system."90 It is Section 310(b) which is referred to here. However, the Community also stressed the exemption clause found in both the FTA and NAFTA, which explicitly recognizes culture as a separate and distinct animal from other goods and services. ${ }^{91}$

\section{GATT}

On November 30, 1994, in a 76-24 vote, the United States Senate approved a 124-nation trade pact known as the General Agreement on Tariffs and

re-transmitting radio and television programmes and for those receiving such programmes; and to submit for public discussion the Commission's thinking on the approximation of certain aspects of Member States' broadcasting . . . law before formal proposals are sent to the European Parliament and to the Council. Television Without Frontiers: Green Paper on the establishment of the Common Market for Broadcasting, especially Satellite and Cable, COM (84) 300 Final (1984).

88. Konigsberg, supra note 55, at 306 (quoting Steven Greenhouse, Europe Reaches TV Compromise - US Officials Fear Protectionism, N.Y.TIMEs, Oct. 4, 1989, at A.1.).

89. By imposing quotas on what was to be shown on European televisions, the "Television Without Frontiers" Directive limited the amount of American programming which could be shown. While this drew flak from the U.S., the Directive also has few fans in Europe itself. As one insider labeled it, "it [the Directive] is an ill-conceived and ill-thought out document, a paper tiger." Furthermore, the Directive is not fully complied with anywhere in Europe. The quotas themselves are becoming useless "in the new universe of digital broadcasting." Michael Williamsadam Dawtrey, GATT Spat Wake-Up on Yank Market Muscle, VARIETY, Dec. 27, 1993, at 45.

90. Id.

91. Id. One French Ministry Official complained that the United States talked about goods while "[w]e talk about culture." This is the fundamental difference between Europeans, who view entertainment as culture and Hollywood, operating at a more commercial level. As the Hollywood saw goes: "If making movies were art, it would be called "show art" not "show business." Forte, supra note 1, at 14. 
Trade (GATT). ${ }^{92}$ This latest round of GATT talks began in 1986 in Uruguay. This Uruguay Round was to have ended back in 1990, but two key French holdouts delayed its completion. One of the French holdouts was the protection of their domestic market and legendary culture against the onslaught of American television. Finally, in December of 1993, the Uruguay Round came to a close.

Reaction from the broadcasting community was generally favorable. ${ }^{93}$ Some of the new provisions GATT included called for the creation of the World Trade Organization, which will oversee the enforcement of member-states' compliance with GATT as well as the inclusion of provisions aimed at the Trade Related Intellectual Property Rights (TRIPS) section. ${ }^{94}$ Under GATT, the copyright protection extended to member-states of the Berne Convention, ${ }^{95}$ will now be enforced by the World Trade Organization.

However, as with NAFTA and FTA, the broadcasting industry and the entertainment industry, as a whole, were the big losers. The French, as "self-appointed defenders of European culture against Hollywood dominance,",96 were successful with their attempts to remove sections dealing with the entertainment industry. Although GATT does not contain any exclusionary language, in the words of U.S. trade representative, Mickey Kantor, "we agreed to disagree. But our differences remain." 97 The Europeans were ultimately successful in keeping audiovisual matters out of GATT, though GATT does call for a periodic five year review. ${ }^{98}$

\section{The Prisoner's Dilemma}

And so it stands, protectionist measures on both sides of the Atlantic Ocean and to the north and south of the United States. Neither party wants to relinquish its restrictions on foreign ownership until the other does, leading to a sort of "prisoner's dilemma." If both sides work together, everyone wins big. If neither side works together, everyone loses big. However, unlike the classic dilemma game, in this instance, one side may act without the other and thereby afford itself great advantages. Simply by opening up its own market to foreign ownership, the

92. Brooks Boliek, Industry's Glad It Got GATT: Senate Approves Trade Pact 76-24; Vote 'A Positive Step,' Valenti Says, HoLLrwood REP., Dec. 2-4, 1994, at 1. The United States House had approved the measure on November 29th, and President Clinton would later sign the pact on behalf of the nation.

93. Id.

94. Id. at 48.

95. The United States joined the Berne Convention in 1986.

96. Follain, supra note 1.

97. Id. This leaves unanswered the question of whether Section 310(b) violates provisions of GATT.

98. Boliek, supra note 92, at 1. 
United States would likely receive a net benefit. In so doing, the U.S. would eliminate much of the justification for other countries protectionist measures.

It is becoming increasingly impossible to find traditional "American" icons that don't have foreign labels stamped on them. Of course, the immediate example that comes to mind is Sony's 1988 acquisition of CBS Records and its acquisition of Columbia Pictures the following year. Since then, Matsushita purchased MCA in 1990 for $\$ 6.13$ billion.9 With these acquisitions, the U.S. domestic work force has increased nearly $400 \%$ through employment at U.S. affiliates of foreign-based firms. During this period of foreign acquisitions, the total assets held by U.S. affiliates of foreign corporations in the film industry increased over $1800 \% .{ }^{100}$

Likewise, opening up United States broadcasting properties to foreign investment would likely encourage other countries to open their broadcasting to American investors. As they stand today, the FCC's restrictions on foreign ownership provide anything but an incentive for foreign governments to relax their restrictions. Ultimately, one country must undoubtedly take the first step. As the most advanced, competitive broadcasting industry in the world, the responsibility of initiating this liberalization falls squarely on the United States. "[T]he Strength of the U.S. Industry and the opportunities derived therefrom would exceed any concomitant risks." 101

Investment has not come without its drawbacks. Many blame the recession of the early ' 90 's on this foreign investment. Others adopt the position of the French and complain of losing their sovereignty. However, any loss in sovereignty is made up for by gains in technological insight from foreign competitors, leading to "increased specialization and a more efficient use of the world's resources by encouraging international trade." ${ }^{\prime 02}$ Furthermore, the need for cultural sovereignty is protected by Section 309(e) of the Communications Act of 1934. "The FCC requires each broadcaster to provide programming that meets the needs of its audience, to reach with its signals its entire community of license, and to locate its studio within the contours of its community of license." 103

With recent expansive growth of cable companies and the deregulation of phone companies, one thing remains clear: In order to protect and preserve the

99. Konigsberg, supra note 55, at 312. Employment figures within those U.S. affiliates of foreign corporations rose from 10,600 in 1986 to 42,700 in 1990. In April of 1995, Matsushita sold its interests in MCA. Eben Shapiro and Thomas R. King, Seagram Buys $80 \%$ of MCA at $\$ 5.7$ Billion, WALL ST. J., Apr. 10, 1995, at A3.

100. Konigsberg, supra note 55, at 313. Assets rose from $\$ 1.194$ billion in 1986 to $\$ 22.166$ billion in 1990 .

101. Id. at 315 .

102. Id. at 316 .

103. Id. at 317 (quoting NATIONAL TELECOMMUNICATIONS AND INFORMATION AdMinistration, U.S. DEPT. Of COMMERCE, Globalization Of the Mass MEDia 1(1993)). 
broadcast industry from competitive pressures it has not felt before, a solution must be reached concerning the foreign ownership restrictions.

\section{POSSIBLE SOLUTIONS TO FOREIGN OWNERSHIP RESTRICTIONS}

The number of voices calling for an end to the foreign ownership restrictions grows almost daily. While it seems most are in agreement that something must be done, no one is sure what to do. ${ }^{104}$ The following suggestions, made by scholars, lawyers, and industry insiders, have made their way to the forefront.

\section{A. The "Do Nothing" and "Let the Courts Handle It" Solution}

One possible solution to the foreign ownership restrictions is to do nothing. Section 310(b)(4) provides the FCC with discretion that it seems to have misinterpreted. The FCC in the past has applied this provision so stringently that it seems to have interpreted it as an absolute bar against more than $25 \%$ ownership. ${ }^{105}$ The FCC's most current decision is completely inconsistent with the prior hard-line stance. ${ }^{106}$ To date, no court has addressed this misreading of Section 310(b)(4).

Foreign Ownership Restrictions can also be challenged on a Fourteenth Amendment constitutional basis. Prohibiting ownership by citizens of U.S. allies even during peacetime is vastly overinclusive, in violation of the 14th Amendment. ${ }^{107}$ Similarly, the foreign ownership rules are underinclusive in some respects. By allowing up to $25 \%$ ownership in broadcast property and up to $100 \%$ in cable television property, it would not be a rational means of protecting

104. In an editorial found in Broadcasting \& Cable, the author writes:

The least that should come from the shambles of FCC foreign ownership policy in the wake of the News Corp/Fox decision is a redefinition of the rules.... The fact is, the FCC's decision to waive News Corp.'s 99\% ownership of the Fox Television Stations effectively repeals foreign ownership restrictions. When Bertelsmann applies to buy CBS, how will the FCC say no? Or should it? When the Bronfmans seek to joint-venture with NBC, what will be the standard? This is no longer a matter than can put off until tomorrow. Somewhere out there, the line has started forming.

Calling Congress; New Legislation For TV Station Ownership Rules Needed. BroADCASTING \& CABLE, May 8, 1995, at 114.

105. J. Gregory Sidak, Free Markets For Telecom: Don't Stifle Global Merger Mania, WALL ST. J., July 6, 1994, at A18. Mr. Sidak is a former deputy general counsel of the FCC.

106. The decision referred to here is, of course, that of the News Corp./Fox decisions issued May 4, and July 31, 1995, and discussed infra.

107. Sidak, supra note 105 at $\mathrm{A} 18$. 
national security to allow an enemy to obtain such ownership. ${ }^{108}$ As Mr. Sidak, a former attorney for the FCC argues, "Since there is a random fit between the ostensible goal of section 310 (b) - protecting our national security - and its means - discriminating against a broad class of aliens - a court should find it in violation of the Equal Protection Clause."109 Finally, Mr. Sidak argues that Section 310(b) infringes upon the rights of foreigners to express their views, clashing with the First Amendment. "The Supreme Court, in a ruling last week, extended more First Amendment protection to the telecom industry. Assuming that the court applies tighter scrutiny to determine whether section 310 (b) complies with the First Amendment, the government would have to show a 'compelling' or 'important' interest in limiting Americans' exposure to foreign opinions."110

The problem with Mr. Sidak's suggestions for leaving it up to the courts to decide is, as generally seen in administrative law cases, the court will usually defer to the judgment of the commission. This is supported by the Telemundo case, seen earlier.

Finally, one author has argued the restrictions against foreign ownership run afoul of the First Amendment right to free speech. ${ }^{11}$ Quoting an article appearing in the June 1995 Columbia Law Review:

Whatever its justifiability intially, Section $310(b)$ 's foreign ownership restriction today represents an anachronistic attempt to limit free speech in America based on xenophobic fears of foreign ideas and influence. The law is one of several examples of broadcast regulations that either have not, or arguably would not, pass constitutional muster under traditional First Amendment analysis. . . . Differential First Amendment treatment of broadcast regulation, critized by some from the very start, has come under increasing attack in recent years as technological and structural developments in the mass media industry steadily erode the constitutional basis for certain forms of broadcast regulation. ${ }^{112}$

Further, Rose points out that as Section 310(b)'s enactment was based on fear of foreign influence, it should be viewed as a "content-based and viewpoint discriminatory restriction on speech ... [ [subject] to the strictest constitutional scrutiny."113

108. Id.

109. Id.

110. Id.

111. See Rose, supra note 55.

112. Id. at 1190.

113. Id. Rose's article, in addition to his excellent attack on First Amendment grounds, also provides important policy reasons for doing away with Section 310(b). 


\section{B. Inclusion in Section 310 of a New Subsection (f): The Reciprocity Clause.}

One suggestion has been to include a new subsection into Section 310 . The suggested subsection would read as follows:

(f) Preference Given to Alien Applicants by Reason of a Bilateral Treaty Between the United States and the Alien's Government

In addition to broadcast licenses which the Commission may issue to aliens pursuant to this Act, the Commission shall issue preferential authorizations, under such conditions and terms as it may prescribe, to permit an alien or representative, whose government has in effect a bilateral agreement with the United States, to obtain a broadcast license, for operation on a reciprocal basis by United States entities, if the Commission finds that the public interest will be served by the granting of such a license. ${ }^{114}$

This proposed subsection limits the amount of foreign ownership while providing the Commission with the ability to prescribe "conditions and terms" by which it will grant the licenses to foreigners. The author of this proposed subsection has suggested that "the Commission initiate a rulemaking process to determine how best to establish these ...."115 Such a rulemaking process would allow the Commission to liberalize foreign investment while simultaneously determining the basis of the status of reciprocal treatment by the foreign government. ${ }^{116}$

114. Konigsberg, supra note 55, at 318.

115. Id. at 319.

116. The reciprocity element was added so as not to cause an "opening of the flood-gates" to foreign investment.

A form of this reciprocity is already evident in cultural exchanges within the entertainment community. The Immigration Act of 1990 promotes reciprocal treatment by ensuring equal treatment for performers from the United States. For example, Equity, the British actors union, and Actor's Equity, its American Counterpart, have agreed on a reciprocal arrangement whereby roles in both countries are allocated to foreign performers on a one-for-one basis. At this time, the U.S.-based Screen Actors Guild ("SAG") and its Canadian counterpart, the Alliance for Canadian Cinema, Television and Radio Artists ("ACTRA"), are actively negotiating an equitable exchange agreement which will serve to facilitate and equalize the number of performers crossing the border to work. Under these arrangements the unions will have the ability to act on each others' behalf to promote foreign performers' rights. 
Meanwhile, NAFTA, while immune from any type of amendment, could be redefined to accommodate the liberalization of foreign ownership through reciprocal legislation.

This "reciprocity" solution has support in Congress. Though he initially suggested completely eliminating the foreign ownership restrictions, which suggestion was later dropped, Representive Michael Oxley (R, Ohio), suceeded in attaching an amendment to the House's Communication's bill that would allow a foreigner to own $100 \%$ of a U.S. telephone company, provided U.S. investors are given reciprocal trade treatment. ${ }^{117}$ Oxley was able to turn to fellow Republican Larry Pressler for support as well as Democrats Edward Markey and Rick Boucher. ${ }^{118}$ However, the Clinton Administration has made it clear that it does not support any relaxation of the current restrictions. ${ }^{119}$

\section{Deregulation - Back to the NBC-Fox Battle}

The final solution to consider is that proposed by the Republicans massive deregulation. Republicans are traditionally known to be deregulatory pro-business. Those in the broadcasting industry were apparently able to sense change even before the November 1994 elections as they scrambled to contribute PAC money and find new lobbyists. ${ }^{120}$

Despite the Republicans' favoritism of deregulation, support for and against legislation involving the broadcast and telecommunication industries has

117. Dennis Wharton, Pols Pounce on ReReg, VARIETY, May 29-June 4, 1995, at 21- 22.

118. See infra note 125 and accompanying text. Pressler (R, S.D.), who heads the Senate Commerce Committee, pushed for a loosening of the foreign ownership regulations so that they were reciprocal with those of trading partners. Brooks Boliek, Still Tinkering with Telcom Bill, HoLLYwOOD REP., Mar. 21, 1995, at 4. Meanwhile, Boucher (D-Va.), who co-sponsored the amendment with Oxley, supports similiar reciprocal action as does Markey (D, Mass.). Brooks Boliek, Dems Hang Tough On Ownership, HoulYwoOD REP., March 6, 1995 at 4.

119. A spokesperson for the Administration told Pressler's committee that while the Administration supported unfettered foreign investment in the telephone industry, the White House drew the line when it comes to easing restrictions on ownership of the broadcasting industry. Citing national security concerns, the spokesperson said, "We should not be too hasty in lifting restrictions on the amount of foreign influence over, or control of, broadcast licenses due to the editorial discretion of broadcasters over the content of transmissions." Clinton Backs FCC Ownership Regs, VARIETY, Mar. 6-12, 1995, at 45.

120. J. Max Robins and Dennis Wharton, Riled By Regs, TV Biz Begs to be Newtered, VARIETY, Jan. 9-15, 1995, at 1, 82. For example, Time-Warner, which had traditionally contributed a majority of its PAC contributions to the Democrats, split an equal amount to both parties this year. Various other changes coming to Washington with the new Congress include replacing the term "Information Superhighway" with the term "Cyberspace" as "highway" is too reminiscent of the road-building images of the President Roosevelt's New Deal and connotes the possibility of speeding tickets. "Cyberspace" on the other hand connotes a "vast freemarket universe with no rules." $I d$. 
generally been bipartisan. ${ }^{121}$ For example, efforts within the House last year were led by current House Telecommunications Subcommittee Chairperson Jack Fields (R., Tex.) and then House Telecommunications Subcommittee Chairperson Edward Markey (D., Mass.). That legislation won overwhelming support in the House. ${ }^{122}$ Meanwhile, in the Senate, opposition to a bill was led by Sen. John Breaux (D., La.,) and Sen. Bob Packwood (R., Ore.), as they had legislation in the workings that was more deregulatory than that offered by Sen. Hollings. ${ }^{123}$

Deregulation of the broadcast industry has not happened in over a decade. ${ }^{124}$ It would appear as those on Capitol Hill do listen to the constituency. In a December 7, 1994 interview, incoming chairman of the Senate Commerce Committee, Larry Pressler (R., S.D.) stated that he would like to see the elimination of the foreign ownership restrictions. ${ }^{125}$ "I would like to see us eliminate, if we could, the foreign ownership cap if other countries did the same. ... It would have to be on a reciprocal basis." ${ }^{126}$ Pressler, a Republican, said he generally supported deregulation, pointing to the example of radio, which in his opinion resulted in more information of a different kind. ${ }^{127}$ In a letter to FCC Chairperson Hundt, Pressler wrote, "Let's face facts. ... The recently approved GATT agreement will require us to repeal or reform the existing foreign ownership provisions of the Communications Act."128 A few days after Pressler made his comments, the FCC announced that it would radically overhaul television ownership rules. ${ }^{129}$

121. One notable exception would be the Kennedy-Hollings affair in 1988 taken against Rupert Murdoch.

122. Brooks Boliek, GOP Gears Up To Retool Media, HoulYwoOd REP., Jan. 3, 1995, at 1 .

123. Id.

124. Dennis Wharton, FCC Revisits Ownership Rules: Overhaul Likely to Increase Number of TV Stations Allowed. VARIETY, Dec. 19, 1994-Jan. 1, 1995, at 40.

125. Brooks Boliek, Pressler Press for End of Foreign Ownership Cap: Comments Made as NBC-Fox Fight Intensifies, HouYwoỌ REP., Dec. 7, 1994, at 1.

126. Id.

127. Pressler also noted, while admitting he did not know the specifics of the Fox-NBC dispute, "The big boys, rather than wanting to compete, are running to Washington." Id

128. Robins and Wharton, supra note 120 , at 84.

129. See supra note 118 . Though not specifically addressing foreign ownership limits, the FCC announced that it would likely be revamping the ownership limits on the number of stations. See supra note 25. Though not official, under the proposed regulations, networks could own as many stations as they wish, so long as they do not reach more than $50 \%$ of U.S. television households. Some discussion will also be made concerning the use of limited liability companies to attract minorities into the broadcast industry. Undoubtedly, some discussion of the foreign ownership rules is bound to come up at meetings. 
Network television itself is one of the most regulated industries in the United States. ${ }^{130}$ There are regulations governing nearly every aspect of the industry. With the huge growth of the cable television, direct broadcasting, and the telephone industries, none of which are subject to nearly the amount of regulation that the broadcasting industry is, many claim it is now time to ease up on some of those regulations, particularly the foreign ownership restrictions. ${ }^{131}$

Preston Paddden, President of Fox Network Acquisition, had this to say, "I think there will be an appropriate relaxation of the broadcast ownership rules. ... We've got the cable industry and the telephone industry about to explode with the video product. If broadcast industry is to remain competitive, it can't be tied to a regulatory structure that dates to $1934 .{ }^{\prime 132}$

\section{E. And What of Fox and the Actors from Our Made-for-TV "Movie of the Week"?}

On May 4, 1995, two weeks after the Mass Media Committee issued a report implicating Fox for failure to reveal fully the nature of its ownership, ${ }^{133}$ the FCC said that Murdoch had indeed exceeded the twenty-five percent rule, but the rule would be waived upon showing of public interest. Fox was given forty-five days to respond. ${ }^{134}$ Most agreed that the decision was, in effect, a waiver, as the same rationale behind granting Fox its license initially still existed. Namely, the birth of the Fox network marked the beginning of a legitimate fourth network to compete with the "Big Three." This was clearly in the public's interest as it has

130. Brooks Boliek, New Congress May Be One to Loosen the Shackles, Houlywood REP., Jan. 11, 1995, at 1.

131. Similarly, many argue that it is now time to do away with the Financial Interest Rule and the Syndication Rule, as well as limiting the Prime Time Access Rule. As one insider stated: "If we can get rid of two of the more incredible millstones around the neck of the network business, even if nothing else happens, that's not going to be a bad year." Id.

132. Id.

133. The Mass Media Bureau, a part of the FCC, issues recommendations to the Chairperson and the other four Commissioners. In its April 24, 1995 report, the FCC staffers recommended that Fox should be forced to bring its ownership into compliance with Section $310(b)$. Further, though Fox was not charged with "misrepresentation" or "lack of candor," the report did conclude that Fox had failed to reveal the true extent of its foreign ownership. Finally, the staff report did recommend that Fox be given the go-ahead with its SF Broadcasting acquistions. Christopher Stern, FCC Staff Proposes Fox Restructuring, BROADCASTING \& CABLE, Apr. 24, 1995, at 9 .

134. Edmund L. Andrews, F.C.C. Vote Gives Murdoch Big Victory on Ownership, N.Y. TIMES, May 5, 1995, at C5. Under the terms of the decision reached by the Commissioners, Fox was not required to restructure, as the earlier staff report had recommended. Instead, Fox was given 45 days to show that it was in the public's interest that it [Fox] be granted a waiver. Id. 
not only created more viewing choices, but also created more jobs and opportunities for the American public. ${ }^{135}$

The agency's decision followed the May 2nd findings of the Federal Trade Commission and the United States Justice Department of Fox's acquisition of two additional stations. ${ }^{136}$ Within the forty-five day period, the News Corporation restructured its ninety-nine percent equity ownership of Fox into debt so that it would be in compliance with Section $310(\mathrm{~b}){ }^{137}$ In the end, the restructuring was not needed as the FCC determined the granting a waiver to Fox was in the public interest. ${ }^{138}$

Meanwhile, Murdoch went about acquiring more clout in the communication industry. ${ }^{139}$ On May 10,1995 , it was announced that MCI would invest $\$ 2$ billion in News Corporation. ${ }^{140}$ The move would ultimately give MCI nearly a fourteen percent interest in the News Corporation and provide Murdoch with more capital with which to acquire more television stations. ${ }^{141}$ Also, Murdoch hopes to launch a direct-to-home satellite service in Latin America. ${ }^{142}$ Such a venture would give Murdoch near-complete global access. In addition to the

135. Id. As one media analyst with Smith Bamey stated, "[t]he News Corp. waiver was done for a particular reason - the company fostered competition. That doesn't necessarily apply to other companies, or open the floodgates to foreign ownership." Christopher Stern \& Steve MoClellan, Foreign Ownership Waiver Likley For Fox. BROAdCASTING \& CABLE, May 8, 1995. at 16.

136. Brooks Boliek, Feds: In Murdoch They Trust, Holl,Ywood REP., May 3, 1995, at 3. Specifically, the FTC and the Justice Department found the proposed acquistions did not involve any antitrust concems. The transaction still needed the FCC's approval. Id.

137. Dennis Wharton, FCC Rules: Fox Can Break Them, VARIETY, July 31-Aug. 6, 1995 , at 21,28 . The FCC determined that the restructuring was merely an attempt to re-label equity as debt. Id. Mean while, the FCC has found that it has its own problems to worry about as it has come under attack. In its May report, the Progress and Freedom Foundation, a conservative research group closely linked to Newt Gingrich, called for the abolishment of the FCC, arguing "that the agency had consistently hurt consumers by blocking competition and innovation." Edmund L. Andrews, A Conservative Group Proposes Abolishing the F.C.C., BroADCASTING \& CABLE, May 31, 1995 at 4. Though it is unlikely that Congress would consider abolishing the FCC, it is quite likely, given the current deregulatory environment, that Congress will significantly curtail the power and influence of the FCC.

138. Id.

139. Murdoch also went "station shopping" in October, 1995. At the annual shareholders meeting, Murdoch announced that the News Corporation would agressively pursue the acquisition of new stations as soon as the pending FCC ownership nules lifted the 12 station cap. Jacqueline Lee Lewes, Murdoch Going Station Shopping, HoLLYwOOD REP., Oct. 11, 1995, at 1.

140. Chris McConnell, News Corp., MCI Make \$2 Billion Partnership, BroAdCAsting \& CABLE, May 15, 1995, at 6.

141. Id

142. Id. 
influx of the $\$ 2$ billion, each company would devote $\$ 200$ million to a joint media venture between them. ${ }^{143}$

\section{CONCLUSION}

The recent battle between Rupert Murdoch's Fox Television Station and General Electric's National Broadcasting Corporation has illuminated an area of Federal Communications Commission regulatory law that calls for a change. Though the outcome of the FCC proceedings taken against Fox by NBC and the NAACP should not affect the need for change, the case does serve as a reminder that our laws in this area have become antiquated.

With the advent of technological breakthroughs in the telecommuncations and broadcasting industries, it has become imperative that the FCC's long-standing tradition of restricting foreign ownership be abandoned. The passage of legislation concerning the North American Free Trade Agreement and the General Agreement on Tariffs and Trade only emphasizes this assertion. Without the burdensome restrictions imposed on the broadcasting industry, we have seen how successful businesses can become. In order to maintain its competitiveness, the restrictions on foreign ownership in the broadcasting industry must be repealed.

David H. Benz*

143. Id.

* J.D. Candidate, 1996, Indiana University School of Law_-Indianapolis. 
